\title{
PENGARUH SELF EFFICACY, LINGKUNGAN KELUARGA DAN PENDIDIKAN KEWIRAUSAHAAN TERHADAP MINAT BERWIRAUSAHA MAHASISWA FAKULTAS EKONOMI UNISDA LAMONGAN
}

\author{
Siti Shoimah \\ Faakultas Ekonomi, Universitas Islam Darul ‘ulum \\ Email: sitishoimah@unisda.ac.id
}

\begin{abstract}
The background of this research is intellectual unemployment which is increasing due to lack of awareness among the younger generation to create their own jobs. The purpose of this study was to analyze the influence of self efficacy, family environment and entrepreneurship education to student interest in entrepreneurship. The sampling technique uses purposive sampling. Respondents in this study amounted to 90 respondents. The independent variables in this study is self efficacy, family environment and entrepreneurship education. Dependent variables in this study is student interest in entrepreneurship. This study uses multiple linear regression analysis using SPSS version 22.0. The results of this study indicate that all the independent variables in this study have an influence on the dependent variable, both partially and simultaneously, while the social media variables, motivation and environment that influence the interest in entrepreneurship have a mediating relationship partially or simultaneously.

Keywords: Self Efficacy, Family Environment, Entrepreneurship education and Student Interest in Entrepreneurship
\end{abstract}

\begin{abstract}
ABSTRAK
Penelitian ini dilatarbelakangi oleh jumlah pengangguran intelektual yang jumlahnya selalu bertambah setiap tahunnya karena kurangnya kesadaran untuk menciptaan lapangan kerja sendiri. Penelitian ini bertujuan untuk menganalisis pengaruh Self Efficacy, Lingkungan Keluarga dan Pendidikan Kewirausahaan terhadap Minat Berwirausaha Mahasiswa. Teknik pengambilan sampel menggunakan purposive sampling. Jumlah Responden dalam penelitian ini berjumlah 90 responden. Variabel Bebas dalam penelitian ini adalah Self Efficacy, lingkungan keluarga dan pendidikan kewirausahaan. Sedangkan variabel terikat dalam penelitian ini adalah minat berwirausaha mahasiswa. Penelitian ini menggunakan Analisis Regresi Linear Berganda menggunakan SPSS versi 22.0. Hasil penelitian ini menunjukkan bahwa seluruh variabel bebas dalam penelitian ini memiliki pengaruh terhadap variabel terikatnya, baik secara parsial maupun simultan, sedangkan variabel Self Efficacy, lingkungan keluarga dan pendidikan kewirausahaan yang mempengaruhi minat berwirausaha memiliki hubungan mediasi secara parsial maupun simultan.
\end{abstract}

Kata Kunci : Self Efficacy, Lingkungan Keluarga, Pendidikan Kewirausahaan dan Minat Berwirausaha Mahasiswa 


\section{PENDAHULUAN}

Pengangguran di Indonesia saat ini masih menjadi masalah terbesar yang sulit untuk diatasi. Hal ini disebabkan semakin banyaknya pelamar pekerjaan dibandingkan lapangan pekerjaan yang ada. Kondisi ini akan semakin diperburuk jika setiap individu hanya berorientasi sebagai pencari pekerja bukan menjadi pencipta pekerjaan.

Banyak lulusan perguruan tinggi yang lebih memfokuskan diri untuk mencari pekerjaan, bukan menciptakan pekerjaan. Banyak juga dari mereka yang menunda kelulusan karena merasa belum siap untuk mendapatkan pekerjaan yang tidak sesuai dengan apa yang mereka inginkan dan targetkan. Mereka lebih banyak bersiap diri untuk ikut serta dalam seleksi penerimaan karyawan dari pada bersiap diri untuk membuka usaha baru.

Mahasiswa diharapkan tidak terlalu menggantungkan hidupnya sebagai orang yang bekerja dengan orang lain melainkan orang yang mampu menciptakan lapangan kerja sendiri. Dalam hal ini Universitas Islam Darul 'Ulum Lamongan khususnya Fakultas Ekonomi telah memberikan bekal para mahasiswanya agar menjadi generasi yang mandiri, kreatif dan inovatif. Fakultas Ekonomi sudah memberikan berbagai macam kegiatan kewirausahaan. Diantaranya terdapat program PKM-K dan terdapat bazar rutin yang diadakan setiap tahun dalam rangka mengembangkan dan menumbuhkan minat berwirausaha bagi mahasiswa.

\section{LANDASAN TEORI}

\section{Self Efficacy}

Self-efficacy adalah penilaian diri, apakah dapat melakukan tindakan yang baik atau buruk, tepat atau salah, bisa atau tidak bisa mengerjakan sesuai denganyang dipersyaratkan. Self-efficacy ini berbeda dengan aspirasi (cita-cita), karena cita-cita menggambarkan sesuatu yang ideal yang seharusnya (dapat dicapai), sedang efikasi menggambarkan penilaian kemampuan diri (Alwisol, 2012: 287). Berikut ini adalah indikator Self Efficacy:

1. Yakin dapat menyelesaikan tugas tertentu: Individu yakin bahwa dirinya mampu menyelesaikan tugas tertentu yang mana individu sendirilah yang menetapkan tugas (target) apa yang harus diselesaikan. 
2. Yakin dapat memotivasi diri untuk melakukan tindakan yang diperlukan untuk menyelesaikan tugas Individu mampu menumbuhkan memotivasi dirinya untuk melakukan serangkaian tindakan yang diperlukan dalam rangka menyelesaikan tugas.

3. Yakin bahwa diri mampu berusaha dengan keras, gigih dan tekunIndividu mempunyai ketekunan dalam rangka menyelesaikan tugasdengan menggunakan segala daya yang dimiliki.

4. Yakin bahwa diri mampu bertahan menghadapi hambatan dan kesulitan Individu mampu bertahan saat menghadapi kesulitan dan hambatan yang muncul serta mampu bangkit dari kegagalan.

5. Yakin dapat menyelesaikan permasalahan di berbagai situasi.Individu mempunyai keyakinan menyelesaikan permasalahan tidak terbatas pada kondisi atau situasi tertentu saja

\section{Lingkungan Keluarga}

Menurut Saroni (2012) mengatakan bahwa lingkungan keluarga mempunyai andil yang sangat besar dalam mempersiapkan anak-anak menjadi seorang wirausahawan di masa yang akan datang. Keluargalah yang mula-mula bertanggung jawab atas pendidikan anak-anak, sehingga keluarga dapat dikatakan sebagai peletak dasar bagi pola perilaku serta perkembangan pribadi anak. Lingkungan keluarga dapat menjadi lingkungan yang kondusif untuk melatih dan mengasah karakter kewirausahaan, yang dapat menjadi bekal pada anak untuk mulai mengarahkan minatnya kelak kemudian hari. Pada lingkungan keluarga tersebut, seorang anak mendapat inspirasi dan dukungan berwirausaha dari keluarga, dan terdapat kegiatan dalam keluarga tersebut yang bermakna belajar kewirausahaan.

Lingkungan keluarga dengan segala kondisi yang ada didalamnya yang meliputi latar belakang anggota keluarga, tradisi keluarga dan cara orang tua mendidik, akan dapat menunjang, membimbing dan mendorong seseorang khususnya mahasiswa untuk kehidupannya mendatang (Koranti, 2013).

Dalam buku Buchari Alma (2014: 8) mengungkapkan bahwa ada pengaruh dari orang tua yang bekerja sendiri, dan memiliki usaha sendiri memiliki kecenderungan anaknya akan menjadi pengusaha pula. Semakin orang tua memberikan dorongan dan 
pengaruh untuk anaknya dalam berwirausaha, maka anak akan cenderung berminat dan menentukan pilihan sebagai wirausaha.

Menurut Slameto (2013:60) mengungkapkan indikator lingkungan keluarga sebagai berikut:

1. Cara orang tua mendidik.

Cara orang tua mendidik anaknya mempunyai pengaruh yang besar terhadap cara belajar dan cara berfikir anaknya.

2. Relasi antar anggota keluarga

Relasi antar anggota keluarga yang paling penting adalah antara orang tua dan anak.

Demi keberhasilan anak, perlu adanya relasi yang baik dalam keluarga.

3. Suasana rumah

Suasana rumah dimaksudkan sebagai situasi atau kejadian-kejadian yang sering terjad di dalam keluarga di mana anak berada dan belajar.

4. Keadaan ekonomi keluarga

Kesulitan ekonomi akan memotivasi atau pendorong anak agar lebih berhasil. Sedangkan orang tua yang berlebih dalam ekonominya kadangkala kurang perhatian terhadap anaknya. Sehingga anak menjadi malas belajar.

5. Latar belakang kebudayaan

Perlu kepada anak ditanamkan kebiasaan-kebiasaab yang mendorong baik, agar mendorong anak menjadi semangat dalam meniti masa depan.

\section{Pendidikan Kewirausahaan}

Pendidikan kewirausahaan bertujuan untuk membentuk manusia secara utuh, sebagai insan yang memiliki karakter, pemahaman dan keterampilan sebagai wirausaha. keahlian dan keterampilan wirausaha banyak didapatkan dari pendidikan kewirausahaan. Berikanlah para siswa penanaman sikap-sikap perilaku untuk membuka bisnis kemudian kita akan membuat mereka menjadi seorang wirausaha yang berbakat (Alma, 2014). Indikator pendidikan kewirausahaan ada 5, yaitu:

1. Pengetahuan tentang usaha yang akan dimiliki

2. Pengetahuan lingkungan usaha

3. Pengetahuan tentang tugas dan tanggung jawab

4. Pengetahuan tentang manajemen dan organisasi

5. Pengetahuan tentang peluang usaha 


\section{Minat Berwirausaha Mahasiswa}

Menurut Zulianto, Santoso, dan Sawiji (2014), minat berwirausaha dalam banyak penelitian dikenal dengan beberapa istilah lain yaitu, motivasi berwirausaha, niat berwirausaha dan intensi kewirausahaan. Minat berwirausaha berarti keadaan sadar pikiran yang mengarahkan perhatian ke arah karir kewirausahaan dan sarana untuk mencapainya (Mwakujonga dan Sesabo, 2012:19). Menurut Anggraneni dan Nurcaya (2016), niat berwirausaha adalah keinginan indvidu melakukan perbuatan atas suatu perilaku tertentu dengan mengambil tindakan memilih berkarir sebagai wirausahawan.

Berdasarkan pengertian di atas dapat disimpulkan bahwa minat berwirausaha merupakan kecenderungan dari individu yang mempunyai keberanian dan keinginan menciptakan suatu bidang usaha melalui ide-ide kreatif, inovatif kemudian merencanakan, mengorganisir, mengatur, menanggung resiko dan mengembangkan usaha yang diciptakannya untuk mencapai tujuan, serta dapat melihat peluang yang ada dan mampu mengelolanya dengan cara bekerja keras, semangat yang tinggi karena minat wirausaha harus melihat ke depan dalam potensi mendirikan usaha. Minat berwirausaha tidak dimiliki dengan begitu saja, melainkan dapat dikembangkan. Indikator minat berwirausaha ada lima yaitu:

1. Perasaan senang

Mahasiswa yang memilki rasa senang atau suka terhadap suatu kegiatan usaha. Maka mahasiswa tersebut akan mempelajari usaha, tidak ada keterpaksaan dan motivasi untuk terus berwirausaha. Oleh karena itu perasaan senang akan memotivasi mahasiswa untuk terus berwirausaha.

2. Ketertarikan

Berhubungan dengan daya gerak yang mendorong untuk cenderung merasa tertarik untuk berwirausaha atau bisa berupa pengalaman afektif yang dirangsang oleh kegiatan berwirausaha itu sendiri.

3. Perhatian

Merupakan konsentrasi atau aktifitas jiwa terhadap pengamatan dan pengertian.Mahasiswa yang memilki minat pada kegiatan usaha tertentu dengan perhatian akan menumbuhkan rasa ingin berwirausaha mahasiswa.

4. Keterlibatan 
Merupakan suatu usaha untuk mengerjakan kegiatan usaha ,dan mampu hal-hal yang berkaitan dengan kegiatan kewirausahaan dan selalu afektif dan berkeinginan untuk berwirausaha dan selalu mengikuti perkembangan dalam bidang kewirausahaan.

\section{Kerangka Konseptual}

Kerangka konseptual penelitian yang menunjukkan pengaruh Self Efficacy, Lingkungan keluarga dan pendidikan kewirausahaan terhadap minat berwirausaha mahasiswa dapat digambarkan sebagai berikut:

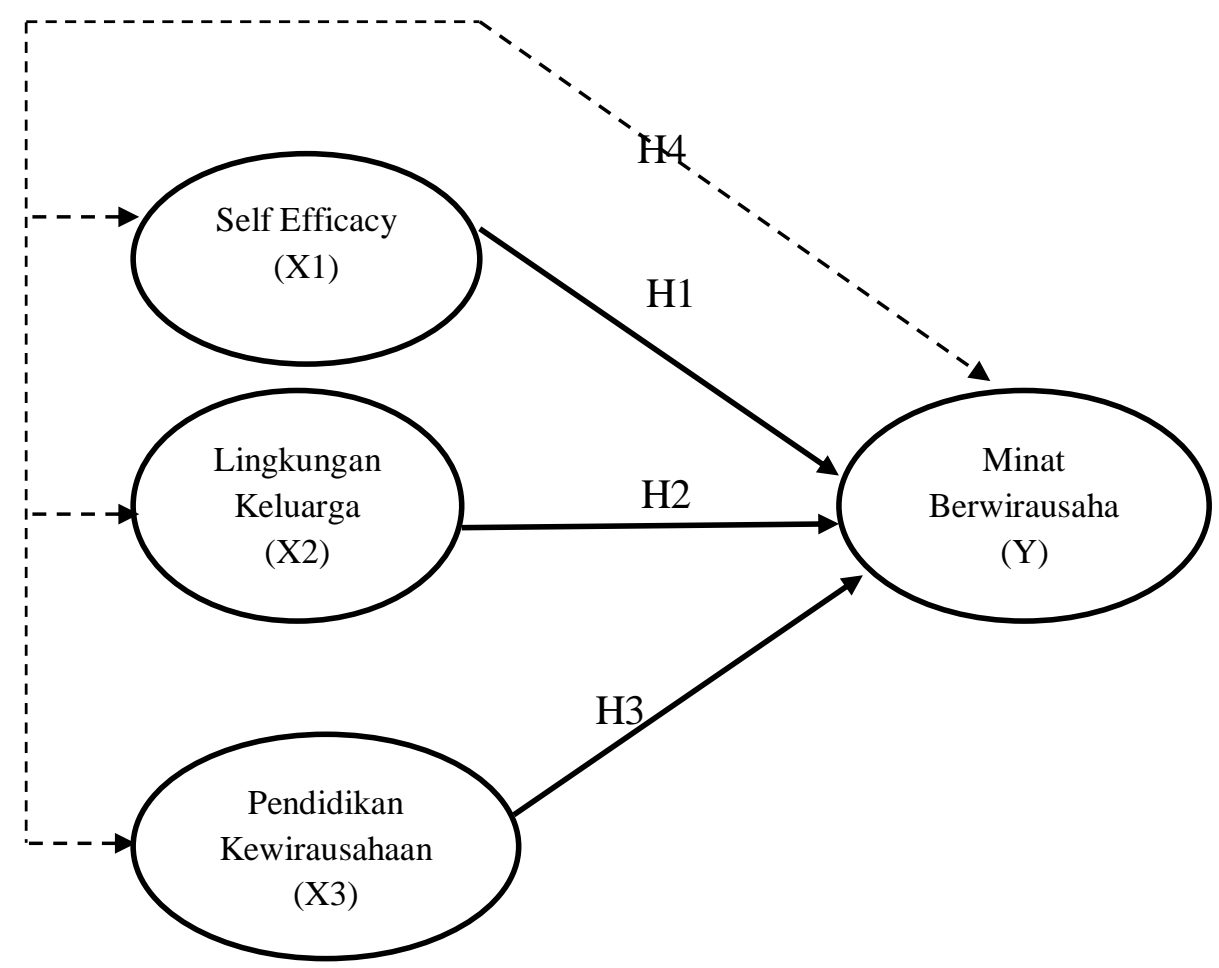

Gambar 1. Hubungan antar Variabel Penelitian

\section{METODE PENELITIAN}

Populasi dalam penelitian ini adalah Mahasiswa Fakultas Ekonomi Unisda yang sudah menempuh mata kuliah kewirausahaan. Jumlah sampel yaitu sebanyak 90 mahasiswa dengan metode purposive sampling. Teknik analisis yang digunakan dalam penelitian ini adalah analisis regresi linear berganda dengan bantuan Software SPSS Versi 22.0.

\section{Uji Validitas}

Menurut Imam Ghozali (2018 : 122) uji validitas digunakan untuk mengukur sah atau valid tidaknya suatu kuesioner. Suatu kuesioner dikatakan sah atau valid jika 
pertanyaan pada kuesioner tersebut mampu mngungkapkan sesuatu yang akan diukur oleh kuesioner itu. Uji signifikansi dilakukan dengan membandingkan nilai $\mathrm{r}$ hitung (nilai Corrected item-Total Correlation pada output Cronbach alpha lebih besar dari $0,3)$ atau dengan nilai $r$ tabel untuk degree of freedom $(\mathrm{df})=\mathrm{n}-2$ ( $\mathrm{n}$ adalah jumlah sampel ) dan tingkat signifikasi 0,05. Pengujian validitas menggunakan ketentuan jika signifikasi dari $r$ hitung atau $r$ hasil $>r$ tabel maka item variabel disimpulkan valid.

\section{Uji reliabilitas}

Suatu Kuesioner dinyatakan reliabel bila nilai Croncbach Alpha bernilai > 0,50. Berdasarkan tabel diatas dapat disimpulkan bahwa kuesioner dinyatakan reliabel karena nilai Cronbach Alpha $>0,50$.

\section{Analisis Regresi Linear Berganda}

Analisis yang digunakan untuk mengetahui seberapa besar pengaruh lebih dari satu variabel bebas terhadap satu variabel terikat. Dalam penelitian dengan judul pengaruh media sosial, motivasi dan lingkungan terhadap minat mahasiswa berwirausaha tersebut, dapat di susun oleh fungsi atau persamaan sebagai berikut (Sugiyono, 2017:267) :

$$
\mathrm{Y}=\alpha+\mathrm{b} 1 . \mathrm{X} 1+\mathrm{b} 2 . \mathrm{X} 2+\mathrm{b} 3 . \mathrm{X} 3+e
$$

Keterangan:

$\mathrm{Y}=$ Minat Berwirausaha

$\alpha=$ Konstata

$\mathrm{X} 1=$ Self Efficacy

X2 = Lingkungan Keluarga

X3 = Pengetahuan Kewirausahaan

$\mathrm{b}_{1} \mathrm{~b}_{2} \mathrm{~b}_{3}=$ Koefisien Regresi

$e=$ Standar Error

Dari hasil pengolahan data dengan menggunakan SPSS 22, di peroleh koefisien regresi seperti dalam tabel 2: 


\section{PEMBAHASAN}

\section{Uji Validitas}

Tabel 1 Uji Validitas

\begin{tabular}{|c|c|c|c|c|c|c|}
\hline & $\mathrm{X} 1.1$ & $\mathrm{X} 1.2$ & $\mathrm{X} 1.3$ & $\mathrm{X} 1.4$ & $\mathrm{X} 1.5$ & $\mathrm{X} 1$ \\
\hline Pearson Correlation & 1 & ,085 & $.347^{\star *}$ & $.476^{* *}$ & $.358^{* *}$ & $.684^{* *}$ \\
\hline Sig. (2-tailed) & & ,426 & ,001 &, 000 & ,001 & ,000 \\
\hline & $\mathrm{X} 2.1$ & $\mathrm{X} 2.2$ & $\mathrm{X} 2.3$ & $\mathrm{X} 2.4$ & $\mathrm{X} 2.5$ & $\mathrm{X} 2$ \\
\hline Pearson Correlation & 1 & $.327^{* *}$ & $.430^{* *}$ & $.297^{\star \star}$ & $.510^{\star *}$ & $.708^{\star *}$ \\
\hline Sig. (2-tailed) & & ,002 &, 000 & ,004 & ,000 & ,000 \\
\hline & X3.1 & X3.2 & X3.3 & X3.4 & X3.5 & X3 \\
\hline Pearson Correlation & 1 & $.322^{* *}$ & $.275^{\star \star}$ & $.287^{\star *}$ & $.475^{* *}$ & $.633^{* *}$ \\
\hline Sig. (2-tailed) & & ,002 & ,009 & ,006 & ,000 & ,000 \\
\hline & Y1 & Y2 & Y3 & Y4 & Y5 & $\mathrm{Y}$ \\
\hline Pearson Correlation & 1 & $.562^{\star \star}$ & $288^{\star \star}$ & $.264^{*}$ & $.515^{\star \star}$ & $.652^{\star \star}$ \\
\hline Sig. (2-tailed) & &, 000 & ,006 & ,012 & ,000 & ,000 \\
\hline
\end{tabular}

Hasil uji validitas pada variabel penelitian Self Efficacy, Lingkungan Keluarga, Pengetahuan Kewirausahaan dan Minat Berwirausaha Mahasiswa yang diolah menggunakan SPSS 22 sebagai berikut. Dari tabel tersebut dapat diketahui bahwa masing-masing item pertanyaan memiliki rhitung $>$ rtabel $(0,205)$. Dengan demikian butir pertanyaan tersebut dinyatakan valid.

\section{Uji reliabilitas}

Tabel 2: Uji Reliabilitas

\begin{tabular}{|l|c|r|}
\hline \multicolumn{3}{|c|}{ Reliability Statistics } \\
\hline & $\begin{array}{c}\text { Cronbach's } \\
\text { Alpha }\end{array}$ & \multicolumn{1}{c|}{ Sig. } \\
\hline X1 & .661 & 0,60 \\
\hline X2 & .749 & 0,60 \\
\hline X3 & .694 & 0,60 \\
\hline Y & .797 & 0,60 \\
\hline
\end{tabular}

Suatu Kuesioner dinyatakan reliabel bila nilai Croncbach Alpha bernilai > 0,60. Berdasarkan tabel diatas dapat disimpulkan bahwa kuesioner dinyatakan reliabel karena nilai Cronbach Alpha $>0,60$. 


\section{Analisis Regresi Linear Berganda}

Dari hasil pengolahan data dengan menggunakan SPSS 22, di peroleh koefisien regresi seperti dalam tabel beikut:

Tabel 3: Hasil Regresi Linear Berganda

\begin{tabular}{|l|r|r|r|r|r|}
\hline & \multicolumn{2}{|c|}{$\begin{array}{c}\text { Unstandardized } \\
\text { Coefficients }\end{array}$} & \multicolumn{1}{c|}{$\begin{array}{c}\text { Standardized } \\
\text { Coefficients }\end{array}$} & & \\
\cline { 2 - 4 } Model & \multicolumn{1}{|c|}{ B } & \multicolumn{1}{c|}{$\begin{array}{c}\text { Std. } \\
\text { Error }\end{array}$} & Beta & \multicolumn{1}{c|}{$\mathrm{t}$} & \multicolumn{1}{c|}{ Sig. } \\
\hline 1 (Constant) & 4.596 & 1.767 & & 2.601 & .011 \\
X1 & .503 & .114 & .455 & 4.426 & .000 \\
X2 & .252 & .095 & .287 & 2.658 & .009 \\
X3 & .061 & .075 & .077 & .815 & .418 \\
\hline
\end{tabular}

a. Dependent Variable: $Y$

Dari tabel diatas, maka persamaan regresi linier berganda yang terbentuk adalah sebagai berikut:

$$
\mathrm{Y}=4,596+0,503 \mathrm{X}_{1}+0,252 \mathrm{X}_{2}+0,061 \mathrm{X}_{3}+e
$$

Keterangan :

- Nilai konstanta positif sebesar 4,596 dapat diartikan bahwa pengaruh variabel bebas, yaitu Self Efficacy, Lingkungan keluarga dan pengetahuan kewirausahaan dapat meningkatkan dan membuat perubahan pada Minat Berwirausaha Mahasiswa.

- b1 (Nilai koefisien regresi X1) sebesar 0,503 mempunyai arti bahwa jika Lingkungan Keluarga (X2) pada Minat Berwirausaha Mahasiswa meningkat satu satuan, maka Y akan meningkat 0,503 atau 50,3\% koefisien bernilai positif.

- b2 (Nilai koefisien regresi X2) sebesar 0,252 mempunyai arti bahwa jika Lingkungan Keluarga (X2) pada Minat Berwirausaha Mahasiswa meningkat satu satuan, maka Y akan meningkat 0,252 atau 25,2\% koefisien bernilai positif.

- b3 (Nilai koefisien regresi X3) sebesar 0,061 mempunyai arti bahwa jika Pengetahuan Kewirausahaan (X3) pada Minat Berwirausaha meningkat satu satuan, maka Y akan meningkat 0,061 atau koefisien bernilai positif.

\section{Uji Hipotesis (Uji T)}

Tabel 4: Hasil Uji T

\begin{tabular}{|c|c|c|c|c|c|}
\hline \multirow[b]{2}{*}{ Model } & \multicolumn{2}{|c|}{$\begin{array}{l}\text { Unstandardized } \\
\text { Coefficients }\end{array}$} & \multirow{2}{*}{$\begin{array}{c}\text { Standardized } \\
\text { Coefficients } \\
\text { Beta }\end{array}$} & \multirow[b]{2}{*}{$t$} & \multirow[b]{2}{*}{ Sig. } \\
\hline & B & $\begin{array}{l}\text { Std. } \\
\text { Error }\end{array}$ & & & \\
\hline 1 (Constant) & 4.596 & 1.767 & & 2.601 & .011 \\
\hline $\mathrm{X} 1$ & .503 & .114 & .455 & 4.426 & .000 \\
\hline $\mathrm{X} 2$ & .252 & .095 & .287 & 2.658 & .009 \\
\hline X3 & .061 & .075 & .077 & .815 & .418 \\
\hline
\end{tabular}


Berdasarkan pada tabel coefficient diatas untuk mengetahui besarnya pengaruh masing-masing variabel independen secara parsial (individual) terhadap variabel dependen adalah sebagai berikut :

\section{Pengaruh Self Efficacy terhadap Minat Berwirausaha Mahasiswa}

Hasil penelitian menunjukkan bahwa koefisien koefisien Media Sosial adalah 4,426, sedangkan tabel ditentukan dengan $\mathrm{df}=(\mathrm{n}-\mathrm{k}-1)(90-3-1)$ maka diperoleh tabel sebesar 0,205 karena thitung > tabel $(4,426>0,205)$, maka Ho ditolak dan Ha diterima, sehingga dapat disimpulkan bahwa variabel Self Efficacy secara parsial atau individual berpengaruh signifikan terhadap Minat Berwirausaha Mahasiswa. Hal ini membuktikan bahwa semakin berkembangnya Media Sosial maka akan semakin tinggi tingkat Minat Mahasiswa Berwirausaha. Semakin tinggi Self Efficacy mahasiswa akan semakin tinggi pula minat berwirausaha mahasiswa. Temuan hasil penelitian ini didukung oleh hasil penelitian Mahshunah dalam Anggraeni dan Nurcaya (2016) yang menyatakan bahwa pabila mahasiswa memiliki Self Efficacy yang tinggi dan merasa bahwa dirinya mampu berwirausaha maka akan semakin tinggi pula niat atau intensi yang dimiliki mahasiswa untuk berwirausaha. Berdasarkan hasil kuesioner pada variabel efikasi diri, mayoritas responden menjawab setuju dengan nilai mean yang tinggi sehingga mengindikasikan bahwa mahasiswa memiliki efikasi diri yang tinggi. Dalam hal Self Efficacy, tiap mahasiswa dalam berwirausaha berbeda-beda. Mayoritas mahasiswa telah memiliki Self Efficacy dalam berwirausaha dengan catatan jika mahasiswa tersebut telah mengetahui bidang bisnis tertentu secara keseluruhan

\section{Pengaruh Lingkungan Keluarga terhadap Minat Berwirausaha Mahasiswa}

Hasil penelitian menunjukkan bahwa koefisien Lingkungan Keluarga adalah 2,658. Sedangkan tabel ditentukan dengan $\mathrm{df}=(\mathrm{n}-\mathrm{k}-1)(90-3-1)$ maka diperoleh nilai tabel sebesar 0,205 karena thitung $>$ tabel $(2,658>0,205)$, maka Ho ditolak dan Ha diterima, sehingga dapat disimpulkan bahwa variabel lingkungan keluarga secara parsial berpengaruh signifikan terhadap Minat Berwirausaha Mahasiswa. Hal ini membuktikan bahwa semakin Lingkungan Keluarga maka akan semakin tinggi tingkat Minat Berwirausaha Mahasiswa. Hasil ini sesuai dengan penelitian sebelumnya yang menyatakan bahwa dorongan dari lingkungan keluarga mahasiswa dapat meningkatkan minat berwirausaha mahasiswa (Pratiwi dan Wardana, 2016). Pernyataan tersebut didukung oleh penelitian Aprilianty dalam Marini dan Hamidah (2014) yang 
menyatakan bahwa lingkungan keluarga memberi pengaruh yang berarti terhadap minat berwirausaha. Pernyataan kelima yaitu "Saya diberi peluang untuk terlibat dalam kegiatan kewirausahaan keluarga sejak kecil" memiliki nilai mean yang terkecil dibanding pernyataan lainnya pada variabel lingkungan keluarga, sehingga keluarga mahasiswa perlu meningkatkan peran serta mahasiswa dalam kegiatan kewirausahaan sejak kecil agar dapat semakin menumbuhkembangkan minat mahasiswa dalam berwirausaha di kemudian hari.. Hal ini didukung oleh Patel dalam Marini dan Hamidah (2014) yang mengatakan bahwa anak-anak yang telah memiliki tanggung jawab dalam keluarga yang besar sejak masih kecil dan telah diberi peluang untuk berperan dan terlibat dalam kegiatan kewirausahaan yang ada dalam keluarga akan membekali anak dengan ketrampilan, pola pikir, keyakian dan nilai-nilai yang diperlukan untuk menjadi pengusaha yang sukses, serta memiliki pengaruh pada perkembangan karakteristik psikologis kewirausahaan individu sejak usia dini.

\section{Pengaruh Pengetahuan Kewirausahaan terhadap Minat Berwirausaha Mahasiswa}

Hasil penelitian menunjukkan bahwa koefisien koefisien Lingkungan adalah 0,815. Sedangkan tabel ditentukan dengan $\mathrm{df}=(\mathrm{n}-\mathrm{k}-1)(90-3-1)$ maka diperoleh nilai tabel sebesar 0,205 karena thitung > tabel $(0,805>0,205)$, maka Ho ditolak dan Ha diterima, sehingga dapat disimpulkan bahwa variabel Pengetahuan Kewirausahaan secara parsial berpengaruh signifikan terhadap Minat Berwirausaha Mahasiswa. Hal ini menunjukkan bahwa semakin banya pendidikan kewirausahaan yang diperoleh mahasiswa, semakin tinggi minat berwirausaha mahasiswa. Hasil ini sesuai dengan penelitian sebelumnya yang menyatakan bahwa pendidikan kewirausahaan berpengaruh positif dan signifikan terhadap minat berwirausaha (Anggraeni dan Nurcaya, 2016). Nilai beta koefisien regresi menunjukkan bahwa pendidikan kewirausahaan merupakan variabel yang berpengaruh pada minat berwirausaha mahasiswa. Hal ini didukung oleh Wedayanti dan Giantari (2016) yang menyatakan bahwa pendidikan kewirausahaan merupakan variabel yang paling besar pengaruhnya terhadap niat berwirausaha mahasiswa. Pendidikan kewirausahaan di FE Unisda mendorong mahasiswa untuk membuka usahanya sendiri dan menjadi entrepreneur sebenarnya. 
Uji F

Tabel 5: Hasil Uji F

\begin{tabular}{|c|c|c|c|c|c|c|}
\hline & Model & $\begin{array}{l}\text { Sum of } \\
\text { Squares }\end{array}$ & df & $\begin{array}{l}\text { Mean } \\
\text { Square }\end{array}$ & $F$ & Sig. \\
\hline \multirow{3}{*}{1} & Regression & 329.931 & 3 & 109.977 & 33.483 & $.000^{\mathrm{b}}$ \\
\hline & Residual & 282.469 & 86 & 3.285 & & \\
\hline & Total & 612.400 & 89 & & & \\
\hline
\end{tabular}

\section{Pengaruh Self Efficacy, Lingkungan Keluarga dan Pengetahuan Kewirausahaan secara bersama-sama terhadap Minat Berwirausaha Mahasiswa}

Dari hasil perhitungan, didapat nilai Fhitung sebesar 33,483. Dengan tingkat signifikansi sebesar 5\% dan df $1=3$ dan df $2=86$, didapat nilai $F_{\text {tabel }}=2,67$. Karena nilai Fhitung $(33,483)>$ nilai Ftabel $(2,67)$ maka dapat disimpulkan bahwa ketiga variabel independen yaitu Self Efficacy, Lingkungan Keluarga dan Pengetahuan Kewirausahaan dengan signifikan memberikan kontribusi yang besar terhadap variabel Minat Berwirausaha Mahasiswa. Maka dapat disimpulkan bahwa Ho ditolak dan Ha diterima, yang berarti terdapat pengaruh secara bersama-sama antara variabel independen terhadap variabel dependen.

\section{Koefisien Determinasi}

Tabel 6: Koefisien Determinasi

Model Summary

\begin{tabular}{|l|r|r|r|r|}
\hline Model & $\mathrm{R}$ & $\mathrm{R}$ Square & \multicolumn{1}{c|}{$\begin{array}{c}\text { Adjusted R } \\
\text { Square }\end{array}$} & $\begin{array}{l}\text { Std. Error of the } \\
\text { Estimate }\end{array}$ \\
\hline 1 & $.734^{\mathrm{a}}$ & .539 & .523 & 1.812 \\
\hline
\end{tabular}

Besarnya persentase variabel Minat Berwirausaha Mahasiswa mampu dijelaskan oleh variabel bebas (koefisien determinasi) ditunjukkan dengan nilai $R$ Square $\left(\mathrm{R}^{2}\right)$ yaitu sebesar 0,523. Dalam hal ini dapat diartikan bahwa Minat Berwirausaha Mahasiswa mampu dijelaskan oleh Self Efficacy, Lingkungan Keluarga dan Pengetahuan Kewirausahaan sebesar 52,3\%, sedangkan sisanya sebesar 47,7\% yang dijelaskan oleh variabel lain yang tidak diteliti dalam penelitian ini. 


\section{SIMPULAN DAN SARAN}

\section{Simpulan}

Berdasarkan hasil penelitian yang telah dilakukan tentang pengaruh Self Efficacy, Lingkungan Keluarga dan Pengetahuan Kewirausahaan terhadap Minat Berwirausaha Mahasiswa dapat diperoleh simpulan sebagai berikut :

1. Self Efficacy berpengaruh langsung terhadap minat berwirausaha mahasiswa (Ha diterima). Yang berarti terdapat hubungan langsung. Apabila Self Efficacy semakin berkembang, maka Minat Berwirausaha Mahasiswa juga akan meningkat. Hipotesis H1 terbukti.

2. Lingkungan Keluarga berpengaruh langsung terhadap minat berwirausaha mahasiswa (Ha diterima). Yang berarti terdapat hubungan langsung. Apabila Lingkungan Keluarga mendukung maka Minat Mahasiswa Berwirausaha juga akan meningkat. Hipotesis $\mathrm{H} 2$ terbukti.

3. Pengetahuan kewirausahaan berpengaruh langsung terhadap minat mahasiswa berwirausaha pada Mahasiswa (Ha diterima). Yang berarti terdapat hubungan langsung. Apabila pengetahuan kewirausahaan tinggi, maka Minat Mahasiswa Berwirausaha juga akan meningkat. Hipotesis H1 terbukti.

4. Self Efficacy, Lingkungan Keluarga dan Pengetahuan kewirausahaan secara bersamasama berpengaruh langsung terhadap Minat Berwirausaha Mahasiswa (Ha diterima). Hipotesis H4 terbukti.

\section{Saran}

Berdasarkan simpulan diatas, maka dapat diajukan saran sebagai berikut:

1. Mahasiswa harus lebih merasa yakin atas kemampuan diri agar dapat termotivasi untuk memulai membuka usaha sendiri tanpa harus menunggu menjadi seorang karyawan di perusahaan.

2. Mahasiswa memiliki usaha keluarga agar senantiasa terlibat dalam agar mampu mengetahui selu beluk bisnis yang sudah dibangun keluarga. Keterlibatan yang tinggi akan menciptakan minat yang besar untuk melanjutkan berwirausaha baik dalam bidang yang sama atau berbeda.

3. Minat Berwirausaha Mahasiswa harus dijadikan prioritas oleh Fakultas, karena dengan mempunyai Minat menjadi seorang wirausaha dapat meminimalisir pengangguran yang sebagian besar sering terjadi pada lulusan sarjana. 
4. Bagi peneliti selanjutnya yang mungkin ingin melakukan penelitian sejenis diharapkan dapat menambah variabel lain seperti Motivasi, kepribadian, sikap mandiri, Media Sosial dan lain-lain yang diduga dapat berpengaruh terhadap Minat Berwirausaha Mahasiswa.

\section{DAFTAR PUSTAKA}

Achmad Syaifudin. (2017), Pengaruh Kepribadian, Lingkungan Keluarga Dan Pendidikan Kewirausahaan Terhadap Minat Berwirausaha Mahasiswa Akuntansi (Studi Kasus Pada Mahasiswa Akuntansi Universitas Negeri Yogyakarta), Jurnal Profita Edisi 8.

Alma,buchori. (2016), Kewirausahaan, Edisi 21, Alfabeta, Bandung.

Anggraeni, A. L., dan Nurcaya, I. N. (2016). Peran Efikasi Diri Dalam Memediasi Pengaruh Pendidikan Kewirausahaan Terhadap Niat Berwirausaha. E-Jurnal Manajemen Unud, 5(4), 2424-2453

Anggiani, Sarfilianty. (2018), Kewirausahaan Pola Pikir Pengetahuan Ketrampilan, Edisi Kedua, Kencana Prenadamedia Group, Jakarta.

Bonnie Farber Canziani. (2018), How entrepreneurship influences other disciplines:Anexamination of learning goals, The International Journal of Management Education,. Hal 5-8, USA.

Dewi, Sayu Ketut Sutrisna. (2017), Konsep dan pengembangan kewirausaahn di Indonesia, Cet-pertama, Deepublish, Yogyakarta.

Ghozali imam. (2018), Aplikasi analisis multivariet dengan progam IBM SPSS 25. Edisi 9. Badan Penerbit Universitas Diponegoro, Semarang.

Hawik Ervina Indoworo. (2016), Menumbuhkan Jiwa Wirausaha Melalui Peran Sosia Media (Studi Kasus Pada Pengguna Internet di Indonesia). Journal Informatika UPGRIS, Vol. 2,No. 1: 46-51.

Herwin Saputri, Mohammad Hari dan Mohammad arief. (2016), Pengaruh Motivasi Berwirausaha Terhadap Minat Berwirausaha Melalui Prestasi Belajar Mata Pelajaran Kewirausahaan Siswa Kelas XI SMK Negeri 1 Kraksaan (Studi Kasus Pada Siswa Kelas XI SMK Negeri 1 Kraksaan). Jurnal Pendidikan Bisnis dan Manajemen, Vol. 2,No. 2: 129-135.

Josia Sanchaya Hendrawan dan Hani Sirine. (2017) berjudul Pengaruh Sikap Mandiri, Motivasi, Pengetahuan Kewirausahaan Terhadap Minat Berwirausaha (Studi pada Mahasiswa Jurusan Manajemen Fakultas Ekonomika dan Bisnis Universitan Kristen Satya Wacana), Skripsi.

Komsi Koranti. (2013), Analisis Pengaruh Faktor Eksternal Dan Internal Terhadap Minat Berwirausaha. Proceeding PESAT (Psikologi, Ekonomi, Sastra, Arsitektur \& Teknik Sipil) Universitas Gunadarma, Vol. 5, No. 2: 68-140.

Kurniati, Edy Dwi. (2015), Kewirausahaan Industri. Edisi pertama. Deepublish. Yogyakarta.

Marini, C. K., dan Hamidah, S. (2014). Pengaruh Self-Efficacy, Lingkungan Keluarga, dan Lingkungan Sekolah Terhadap Minat Berwirausaha Siswa SMK Jasa Boga. Jurnal Pendidikan Vokasi, 4(2), 195-207

Muhammad Hasym Alfaruk. (2016), Pengaruh Pemanfaatan Sosial media, Motivasi dan Pengetahuan terhadap minat Berwirausaha Pada Mahasiswa Ekonomi Di 
Universitas Muhammadiyah Sidoarjo. (Studi Kasus Pada Mahasiswa Ekonomi Di Universitas Muhammadiyah Sidoarjo). Journal Ekonomi Pendidikan dan Kewirausahaan,. Hal 166-167.

Pratiwi, Y., dan Wardana, I. M. (2016). Pengaruh Faktor Internal dan Eksternal Terhadap Minat Berwirausaha Mahasiswa Fakultas Ekonomi dan Bisnis Universitas Udayana. E-Jurnal Manajemen Unud, 5(8), 5215-5242

Sugiyono. (2017), Metode Penelitian Pendidikan Pendekatan Kuantitatif, Kualitatif, dan $R \& D$, Alfabeta, Bandung.

Supriyanto. (2014), How To Become A Successful Entrepreneur, CV Andi Offset. Yogyakarta.

Suryana, Yuyus. (2011), Kewirausahaan Pendekatan Karakteristik Wirausahawan Sukses, Cetakan kedua, Edisi pertama, Kencana, Jakarta.

Wedayanti, N. P., \& Giantari, I. G. (2016). Peran Pendidikan Kewirausahaan Dalam Memediasi Pengaruh Norma Subyektif Terhadap Niat Berwirausaha. E-Jurnal Management Unud, 5(1), 533-56

Zulianto, M., Santoso, S., dan Sawiji, H. (2014). Pengaruh Efikasi Diri dan Pendidikan Kewirausahaan

terhadap Minat Berwirausaha Mahasiswa Pendidikan Tata Niaga Fakultas Ekonomi Universitas Negeri Malang Tahun 2013. Jurnal Pendidikan Insan Mandiri, 3(1), 59-72 